\title{
MicroRNAs expression in CD4 T cells from HTLV-1 individuals
}

\author{
Kátia Kaori Otaguiri , Mariana Tomazini Pinto ${ }^{1,2}$, Evandra Strazza Rodrigues ${ }^{1,2}$, Virgínia Mara de Deus Wagatsuma ${ }^{1}$, \\ Maurício Cristiano Rocha Júnior ${ }^{1,2}$, Osvaldo Massaiti Takayanagui ${ }^{3}$, Dimas Tadeu Covas ${ }^{1,3}$, Simone Kashima ${ }^{1,2^{*}}$ \\ From 16th International Conference on Human Retroviruses: HTLV and Related Viruses \\ Montreal, Canada. 26-30 June 2013
}

$\mathrm{HAM} / \mathrm{TSP}$ is an inflammatory manifestation of central nervous system caused by HTLV- 1 and the mechanism of HAM/TSP development is no well elucidated. Currently, a promising approach on the physiopathogenesis of viral infections has been the evaluation of microRNAs (miRNAs) role. There are few data involving CD4+ $\mathrm{T}$ cells miRNA expression in HTLV-1 infection as well as in HAM/TSP establishment. To identify miRNAs differentially expressed in CD4+ T cells among noninfected individuals (CT), asymptomatic (HAC) and HAM/TSP patients we applied quantitative real time PCR. The analysis of miRNA expression profile in these cells showed 56 and 10 miRNAs upregulated 1.5 times in HAM/TSP and HAC groups, respectively. miR-125b1-1 was upregulated in HAC group and miR-146a in HAM/TSP. Target prediction by in silico analysis showed that IFNG was a potentially miR-125b-1-1 target and IRAK1 and TRAF6 were miR-146a targets. IFNG expression was 1.3 higher in HAC than CT group and 1.8 higher in HAM/TSP than CT group. It was observed that TRAF6 expression was 15.7 and 1.5 times higher in HAM/TSP and HAC groups, respectively. There was no difference of IRAK1 expression among the three groups. Overexpression assays of miR-125b-1-1 altered IFNG expression and overexpression of miR-146a altered IRAK1 gene and protein expression. The results revealed that miRNAs could modulate genes and proteins during HTLV-1 infection. miR-125b and IFNG gene correlation suggests that miR-125b seems to contribute to HAM/TSP development. Besides, interaction between miR-146a and IRAK1/TRAF6 suggests that miR-146a seems to contribute to HTLV-1 establishment in $\mathrm{CD} 4+\mathrm{T}$ cells.

'Regional Blood Center of Ribeirão Preto, University of São Paulo (USP), Brazil Full list of author information is available at the end of the article
Authors' details

'Regional Blood Center of Ribeirão Preto, University of São Paulo (USP), Brazil. ${ }^{2}$ Faculty of Pharmaceutical Sciences of Ribeirão Preto, USP, Brazil.

${ }^{3}$ Faculty of Medicine of Ribeirão Preto, USP, Brazil.

Published: 7 January 2014

doi:10.1186/1742-4690-11-S1-P111

Cite this article as: Otaguiri et al:: MicroRNAs expression in CD4 T cells from HTLV-1 individuals. Retrovirology 2014 11(Suppl 1):P111.

Submit your next manuscript to BioMed Central and take full advantage of:

- Convenient online submission

- Thorough peer review

- No space constraints or color figure charges

- Immediate publication on acceptance

- Inclusion in PubMed, CAS, Scopus and Google Scholar

- Research which is freely available for redistribution
C Biomed Central

(0) 2014 Otaguiri et al; licensee BioMed Central Ltd. This is an Open Access article distributed under the terms of the Creative Commons Attribution License (http://creativecommons.org/licenses/by/2.0), which permits unrestricted use, distribution, and reproduction in any medium, provided the original work is properly cited. The Creative Commons Public Domain Dedication waiver (http:// creativecommons.org/publicdomain/zero/1.0/) applies to the data made available in this article, unless otherwise stated. 